\title{
The Influence of Recreational Crabbing Regulations on Diamondback Terrapin By-Catch
}

Randolph Chambers

rmcham@wm.edu

Follow this and additional works at: https://scholarworks.wm.edu/aspubs

Part of the Biology Commons

\section{Recommended Citation}

Chambers, Randolph, The Influence of Recreational Crabbing Regulations on Diamondback Terrapin ByCatch (2014).

$10.1656 / 045.021 .0103$

This Article is brought to you for free and open access by the Arts and Sciences at W\&M ScholarWorks. It has been accepted for inclusion in Arts \& Sciences Articles by an authorized administrator of W\&M ScholarWorks. For more information, please contact scholarworks@wm.edu. 


\section{BioOne COMPLETE}

\section{The Influence of Recreational Crabbing Regulations on Diamondback Terrapin By-Catch}

Authors: Amy J. Upperman, Timothy M. Russell, and Randolph M. Chambers

Source: Northeastern Naturalist, 21(1) : 12-22

Published By: Eagle Hill Institute

URL: https://doi.org/10.1656/045.021.0103

BioOne Complete (complete.BioOne.org) is a full-text database of 200 subscribed and open-access titles in the biological, ecological, and environmental sciences published by nonprofit societies, associations, museums, institutions, and presses.

Your use of this PDF, the BioOne Complete website, and all posted and associated content indicates your acceptance of BioOne's Terms of Use, available at www.bioone.org/terms-of-use.

Usage of BioOne Complete content is strictly limited to personal, educational, and non-commercial use. Commercial inquiries or rights and permissions requests should be directed to the individual publisher as copyright holder.

BioOne sees sustainable scholarly publishing as an inherently collaborative enterprise connecting authors, nonprofit publishers, academic institutions, research libraries, and research funders in the common goal of maximizing access to critical research. 


\title{
The Influence of Recreational Crabbing Regulations on Diamondback Terrapin By-catch
}

\author{
Amy J. Upperman ${ }^{1}$, Timothy M. Russell ${ }^{1}$, and Randolph M. Chambers ${ }^{1, *}$
}

\begin{abstract}
Malaclemys terrapin terrapin (Northern Diamondback Terrapin) is susceptible to drowning in commercial-style pots used for the Callinectes sapidus (Blue Crab) fishery. Regulations to reduce by-catch mortality vary by state. We compared three different regulatory strategies with respect to crab catch and their relative effectiveness at reducing terrapin by-catch. To mimic their possible use by recreational crabbers, we grouped and fished together ten unbaited crab pots with no by-catch reduction devices (BRDs), ten with large BRDs, and ten with small BRDs in a tidal creek in southeastern Virginia. Over 24 sampling days, the total legal crab catch $(\mathrm{crabs} \geq 12.7 \mathrm{~cm})$ in pots with no BRDs $(29.9 \pm 10.0 \mathrm{SD}$ crabs pot $\left.{ }^{-1}\right)$ and large BRDs $\left(27.9 \pm 6.2\right.$ crabs pot $\left.^{-1}\right)$ was significantly greater than catch in pots with small BRDs $\left(14.0 \pm 5.8 \mathrm{crabs} \mathrm{pot}^{-1}\right)$. Legal crabs varied in average size from 14.1 $\pm 1.2 \mathrm{~cm}, 14.0 \pm 1.2 \mathrm{~cm}$, and $13.7 \pm 1.0 \mathrm{~cm}$ from pots with no BRDs, large BRDs, and small BRDs, respectively, but these differences were not significant. Of a by-catch of 71 terrapins, 69 were from pots with no BRDs, 2 from pots with large BRDs, and none from pots with small BRDs. The potential mortality of terrapins in pots without BRDs would have reduced the population in this tidal creek by $42 \%$ in just 24 days. Based on these results, regulations requiring the use of large BRDs come closest to the objective of reducing by-catch mortality of terrapins without a large effect on crab capture in Virginia. Both recreational crabbing and commercial crabbing with no BRDs on pots in terrapin habitat can contribute to declines in local terrapin populations.
\end{abstract}

\section{Introduction}

Malaclemys terrapin terrapin (Schoepff) (Northern Diamondback Terrapin) lives in estuaries along the Atlantic coast of the US. As the only exclusively brackish turtle species in North America, the terrapin is recognized as a potential keystone predator in tidal marshes (Silliman and Bertness 2002), where terrapin consumption of snails and other invertebrates (Butler et al. 2012, Tucker et al. 1995, Whitelaw and Zajac 2002) may contribute to top-down control of herbivore populations grazing on marsh grasses.

Throughout its range, Northern Diamondback Terrapin habitat overlaps a large commercial and recreational fishery for Callinectes sapidus Rathbun (Blue Crab). In the northeast, the crab fishery is more intense in Virginia (VA), Maryland (MD), Delaware (DE), New Jersey (NJ), and New York (NY) relative to Connecticut (CT), Rhode Island (RI), and Massachusetts (MA), where crabbing with commercialstyle crab pots is not allowed. Numerous studies have documented the mortality of juvenile and adult terrapins as by-catch in crab pots (Bishop 1983, Dorcas et al.

\footnotetext{
${ }^{1}$ Keck Environmental Lab, College of William and Mary, Williamsburg, VA 23187.

"Corresponding author - rmcham@wm.edu.
}

Manuscript Editor: Todd Rimkus 
2007, Gibbons et al. 2001, Grosse et al. 2009, Roosenburg 2004, Wood 1997). The mortality of adult female terrapins is particularly worrisome since turtle population models indicate that survival of adult females is more critical to population maintenance than, for example, reproductive output and recruitment of hatchlings (Heppell et al. 1999, Mitro 2003).

In response to the demonstrated negative impacts of the crab fishery on Diamondback Terrapins, regulations to reduce by-catch mortality have been enacted in some states (Table 1). The regulations require the use of by-catch reduction devices (BRDs), though the sizes of the BRDs vary by state. Further, the regulations target either within-state geographic areas where commercial and recreational crabbing overlap with terrapin habitat (NJ, NY) or recreational crabbers specifically (MD, $\mathrm{DE})$. No BRD regulations are in place in VA. Whereas in most states the majority of commercial crabbers set pots in open-water portions of estuaries, bait and check them daily, and do not overlap significantly with terrapin habitat (Hart and Crowder 2011), recreational crabbers typically set their pots in nearshore waters around private docks and may not bait and check pots on a daily basis. Because of their usual nearshore location in terrapin habitat and the demonstrated by-catch of terrapins even in unbaited pots (Hoyle and Gibbons 2000, Morris et al. 2011), recreational crab pots have been a regulatory focus.

Experimental results from studies testing the relative merits of different BRD regulatory strategies on both crab catch and terrapin by-catch have been equivocal (Hart and Crowder 2011, Roosenburg 2004). Some studies conclude the use of BRDs reduces terrapin mortality without affecting crab catch significantly (Butler and Heinrich 2007, Morris et al. 2011, Rook et al. 2010, Roosenburg and Green

Table 1. Review of state regulations for by-catch reduction devices (BRDs) on commercial-style crab pots, giving BRD size, whether regulations apply to commercial and recreational crabbing, and notes on the specific locations where or user groups to whom the regulations apply. Com. $=$ commercial, rec. $=$ recreational

\begin{tabular}{|c|c|c|c|c|}
\hline State & BRD Size & Com. & Rec. & Notes \\
\hline New York ${ }^{\mathrm{A}}$ & $5 \mathrm{~cm}$ x $15.2 \mathrm{~cm}(2 " \times$ x") & Yes & Yes & $\begin{array}{l}\text { Large BRD: Only in waters listed } \\
\text { by NY Department of Environ- } \\
\text { mental Conservation }\end{array}$ \\
\hline New Jersey ${ }^{B}$ & $5 \mathrm{~cm}$ x $15.2 \mathrm{~cm}(2 " \times 6 ")$ & Yes & Yes & $\begin{array}{l}\text { Large BRD: Only in waters }<150 \\
\mathrm{ft} \text { from shoreline to shoreline } \\
\text { at mean low water }\end{array}$ \\
\hline Delaware $^{\mathrm{C}}$ & $4.5 \mathrm{~cm}$ x $12 \mathrm{~cm}(1-3 / 4 ”$ x 4-3/4”) & No & Yes & $\begin{array}{l}\text { Small BRD: Recreational crab- } \\
\text { bing only }\end{array}$ \\
\hline Maryland $^{\mathrm{D}}$ & $4.5 \mathrm{~cm}$ x $12 \mathrm{~cm}(1-3 / 4 ”$ x 4-3/4”) & No & Yes & $\begin{array}{l}\text { Small BRD: Recreational crab- } \\
\text { bing only }\end{array}$ \\
\hline Virginia $^{\mathrm{E}}$ & N/A & N/A & N/A & $\begin{array}{l}\text { No BRD: Not required on any } \\
\text { pots }\end{array}$ \\
\hline
\end{tabular}

${ }^{\text {A } h t t p: / / w w w . d e c . n y . g o v / r e g s / 4011 . h t m l ~}$

${ }^{B}$ http://www.state.nj.us/dep/fgw/pdf/2012/comregs12.pdf

${ }^{\mathrm{C}}$ http://www.dnrec.delaware.gov/fw/Fisheries/Documents/rec\%20crab\%20pot\%20summary.pdf

Dhttp://www.dnr.state.md.us/fisheries/regulations/crabpot-trd/crabpot.asp

${ }^{\mathrm{E}}$ http://www.mrc.state.va.us/regulations/recfish\&crabrules.shtm 
2000), but another observed a significant decrease in crab catch (Cole and Helser 2001). Some of these studies have been completed in different estuaries and often have used different-sized BRDs, thereby making comparisons between them difficult. Roosenburg (2004) suggested that geographic variation in crab and terrapin size could influence the results of BRD studies and create the need for different state-by-state regulations.

For the present study, our objective was to test the influence of different regulatory strategies employed by different states on the capture of crabs and the by-catch of terrapins. Our goal was to determine the relative impacts of the use of no BRDs with the use of two sizes of BRDs affixed to pots for recreational crabbing. We completed a grouped comparison of the capture of crabs and by-catch in pots employing these three different regulatory strategies and use the results to make recommendations for BRD implementation in VA.

\section{Field Site Description}

The study was completed in Felgates Creek $\left(37.2667^{\circ} \mathrm{N}, 76.5850^{\circ} \mathrm{W}\right)$, a tributary to the York River sub-estuary of Chesapeake Bay in southeastern VA (Fig. 1). Felgates Creek lies entirely within the boundary of the York River Naval Weapons Station military installation, and thus public access has been restricted for decades. As a result, no commercial or recreational crabbing occurs in Felgates Creek. Vegetation in the 105-ha wetland-creek complex is dominated by Spartina alterniflora (Saltmarsh Cordgrass), and the surrounding upland forest is mostly pine and oak. The tidal range is $1.3 \mathrm{~m}$. The most significant predators of Diamondback Terrapins in Felgates Creek include Procyon lotor (L.) (Raccoon) that depredate terrapin nests, and Haliaeetus leucocephalus (L.) (Bald Eagle) and Lontra canadensis (Schreber) (North American River Otter) that prey on juvenile and smaller adult turtles (R.M. Chambers, pers. observ.; Clark 1982). The salinity varied from $24 \mathrm{ppt}$ to $12 \mathrm{ppt}$ across ten sampling sites chosen to reflect a potential range in environmental conditions throughout which terrapins were known to occur, with three sites located near the mouth of Felgates Creek into the York River, four sites located near a bridge $1.5 \mathrm{~km}$ upstream from the mouth, and three sites located $2.1 \mathrm{~km}$ upstream from the mouth (Fig. 1).

\section{Methods}

We completed data collection over 24 non-consecutive sampling days between 6 June and 26 July 2012. At each of the 10 sampling sites, we placed three commercial-style crab pots $(60 \mathrm{~cm}$ x $60 \mathrm{~cm}$ x $60 \mathrm{~cm})$ - one from each experimental treatment group - approximately $5 \mathrm{~m}$ apart. "No BRD" pots were not fitted with any BRDs. "Large BRD" pots were fitted with 5-cm x 15.2-cm plastic, rectangular BRDs affixed to each of the four funnel openings to the pots. "Small BRD" pots were fitted with $4.5-\mathrm{cm} \times 12-\mathrm{cm}$ plastic BRDs of the same material. The pots were not fitted with cull rings, which are 6-cm circular openings in the sides of pots used by commercial crabbers to allow smaller crabs to escape capture. We modified all 
30 pots with chicken wire "chimneys" (height $=120 \mathrm{~cm}$ ) attached to an opening cut into the top corner of each crab pot, allowing terrapins access to the surface if captured in the crab pots. Chimneys were held in place by an elastic cord attached to a wooden stake driven into the creek bed. We assumed any effect of chimneys or stakes was equal among all three treatment groups.

To determine crab catch and by-catch in untended pots (mimicking pots checked infrequently by recreational crabbers and derelict pots lost by commercial crabbers), we deliberately did not bait the pots. On each sampling day, sampling of crabs and by-catch was completed 20-28 hours after setting the pots. The number and sex of both legal (point-to-point carapace width greater than $12.7 \mathrm{~cm}$ ) and sublegal crabs were recorded in each pot per site, and all crabs were released. We identified

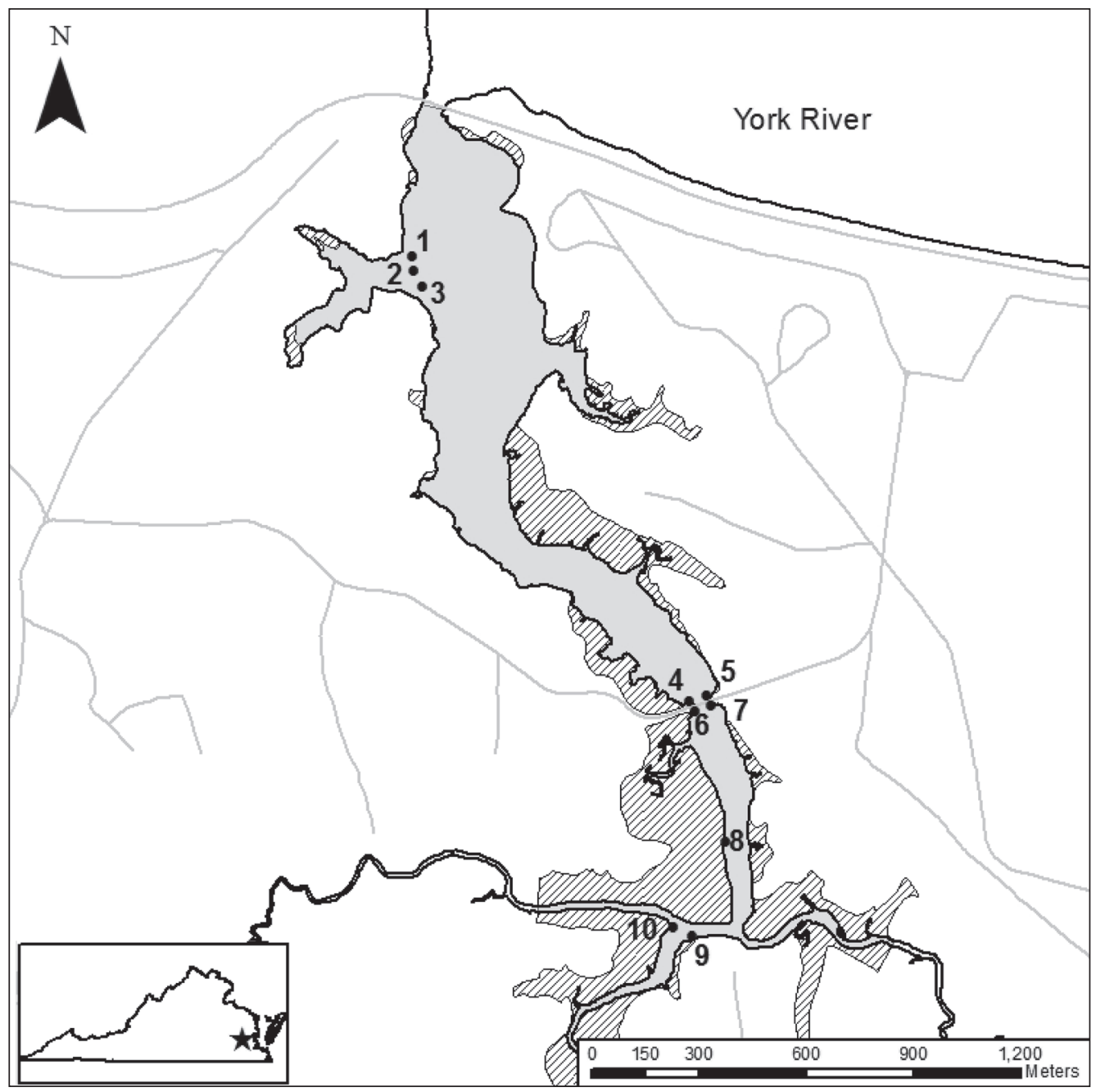

Figure 1. Map of Felgates Creek in southeastern Virginia showing the general clustering of sampling sites near the mouth (1-3), around the bridge (4-7), and farther upstream (8-10). Light gray lines are roads; open water and tidal marsh habitats are shown in solid gray fill and diagonal hatching, respectively. 
the sex and measured the carapace width and shell height of any terrapins captured as by-catch. Using a file, we notched a unique numeric code on the marginal scutes of unmarked terrapins and released them. We identified all fish by-catch to species prior to release.

We calculated the mean \pm standard deviation of legal crab captures and terrapin by-catch from pots without BRDs and compared them among the three locations in Felgates Creek using ANOVA with Tukey HSD post-hoc comparisons. We also used ANOVA with post-hoc comparisons to evaluate the average daily number and average size of legal crabs among the three BRD treatments. For all statistical analyses, the significance level was set at $\alpha=0.05$. Finally, we compared the number of terrapins captured in Felgates Creek during the study period with the estimated population size in the creek from Morris et al. (2011).

\section{Results}

For this study using unbaited crab pots, we captured a total of 717 Blue Crabs, over half of which were legal size ( $\geq 12.7 \mathrm{~cm}$; Table 2$)$. Crab catch was dominated by males (94\% of total). The by-catch included a total of 71 Diamondback Terrapin captures and 40 fish captures comprising Leiostomus xanthurus Lacépède (Spot Croaker), Micropogonias undulatus (L.) (Atlantic Croaker), Dorosoma cepedianum (Lesueur) (Gizzard Shad), and Sciaenops ocellatus (L.) (Red Drum).

The daily average catch per unit effort (CPUE) of legal-size crabs and terrapins in pots without BRDs at the mouth, bridge, and upstream sites varied significantly (ANOVA: $F=11.05$, df $=2, P<0.001$ ). Significantly more legalsize crabs were captured at the mouth of the creek relative to bridge and upstream locations (post-hoc comparisons: $P<0.005$; Fig. 2). No significant difference was found between the crab CPUE at the bridge and upstream sites $(P=0.277)$. The daily average CPUE of terrapins among sites was significantly different (ANOVA: $F=6.38, \mathrm{df}=2, P=0.002$ ) and was greater at the bridge location relative to the mouth and upstream locations (post-hoc comparison: $P<0.05$; Fig. 2 ). The CPUE of terrapins between mouth and upstream locations was not significantly different $(P=0.729)$.

Over the entire study, the average total number of legal crabs captured per pot varied significantly by BRD regulation (ANOVA: $F=12.97$, df $=2, P<0.001$; Fig. 3). Significantly fewer crabs were captured in pots fitted with small BRDs relative to pots fitted with either large BRDs or no BRDs (post-hoc comparisons: $P<$ 0.001). Although fewer crabs were captured per pot fitted with large BRDs relative

Table 2. Summary from 24 sampling dates of crab and by-catch from unbaited pots with no BRDs and those fitted with small and large BRDs.

\begin{tabular}{lcccc} 
Catch & Small BRD & Large BRD & No BRD & Total \\
\hline Total crabs & 139 & 279 & 299 & 717 \\
Legal crabs & 67 & 138 & 168 & 373 \\
Terrapins & 0 & 2 & 69 & 71 \\
Fish & 5 & 10 & 25 & 40 \\
\hline
\end{tabular}




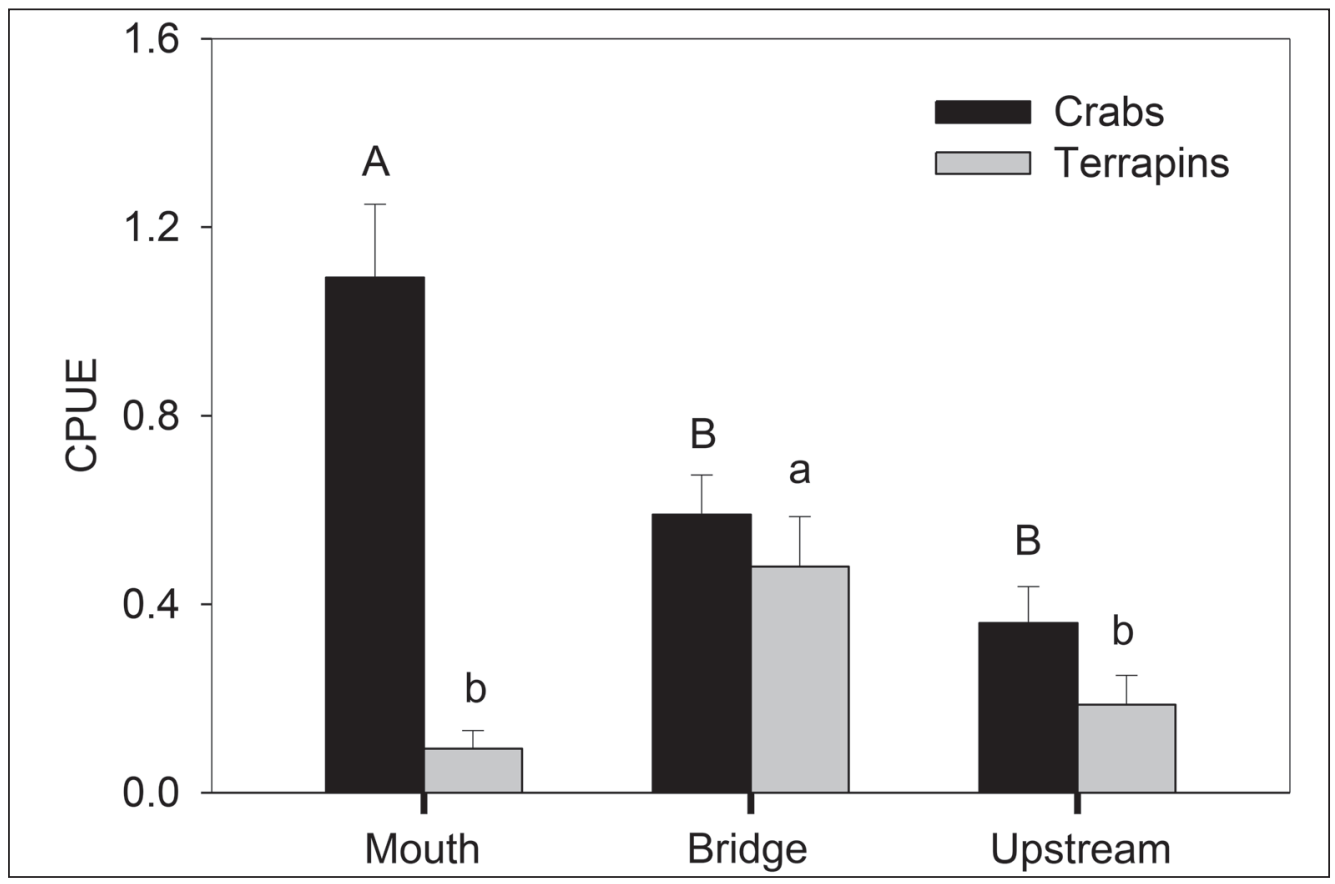

Figure 2. Catch per unit effort (CPUE) for crabs and terrapins from pots without BRDs placed in locations near the mouth of Felgates Creek, around the bridge, and farther upstream. Capital and lowercase letters refer to the results of post-hoc comparisons of crab catch and terrapin by-catch, respectively, among sampling locations.

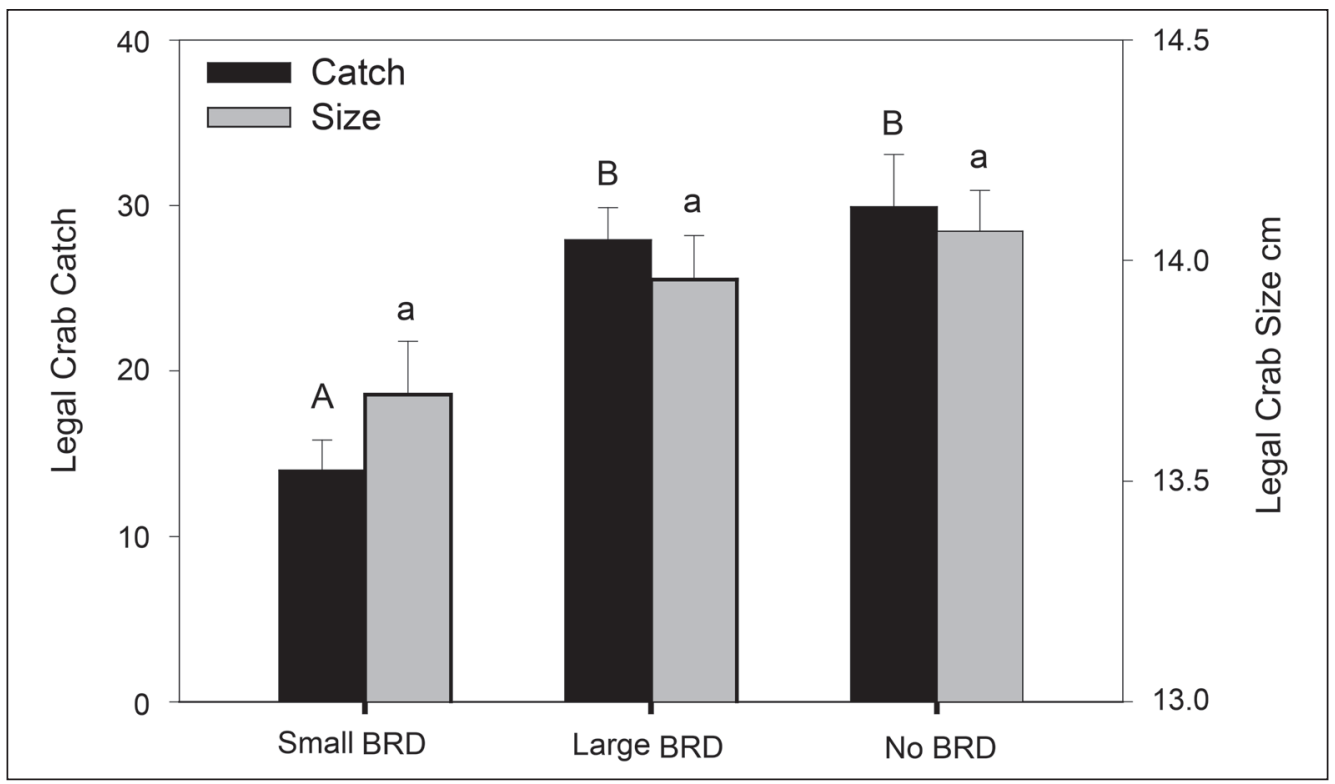

Figure 3. Comparison of average total legal crab catch and average crab size from pots conforming to different BRD regulations ( $n=10$ pots for each BRD group). Capital and lowercase letters refer to the results of post-hoc comparisons among pot types with respect to crab catch and crab size, respectively. 
to pots with no BRDs $(29.9 \pm 10$ vs. $27.9 \pm 6.2)$, the difference was not significant (post-hoc comparison: $P=0.828$ ). The largest crabs were captured in pots fitted with no BRDs $(14.1 \pm 1.2 \mathrm{~cm})$, and the smallest crabs were captured in pots fitted with small BRDs $(13.7 \pm 1.0 \mathrm{~cm})$, but the differences in legal crab size among BRD regulations were not significant (ANOVA: $F=2.47, \mathrm{df}=2, P=0.086$ ).

We captured 23 male terrapins with three additional recaptures, and 33 female terrapins with 12 additional recaptures. For the terrapin captures, we plotted carapace width and shell height relative to the opening in pots constrained by BRD regulation (Fig. 4). Only two of the captured terrapins were small enough to fit through the small BRD opening (shell height $<4.5 \mathrm{~cm}$ ), neither of which was captured in a pot fitted with small BRDs. Although 14 terrapins could have passed through the openings into pots fitted with large BRDs, only two terrapins were captured in large BRD pots. Twelve of the 14 terrapins small enough to fit into large BRD pots were adult males, which—owing to sexual size dimorphism—are generally smaller than adult females.

Morris et al. (2011) used the Schnabel method at Felgates Creek in 2009 to estimate a terrapin population size of 133 . We had 54 original terrapin captures in pots without BRDs (plus 15 recaptures); if these terrapins had drowned in the pots, the loss would have been $42 \%$ of the estimated population size.

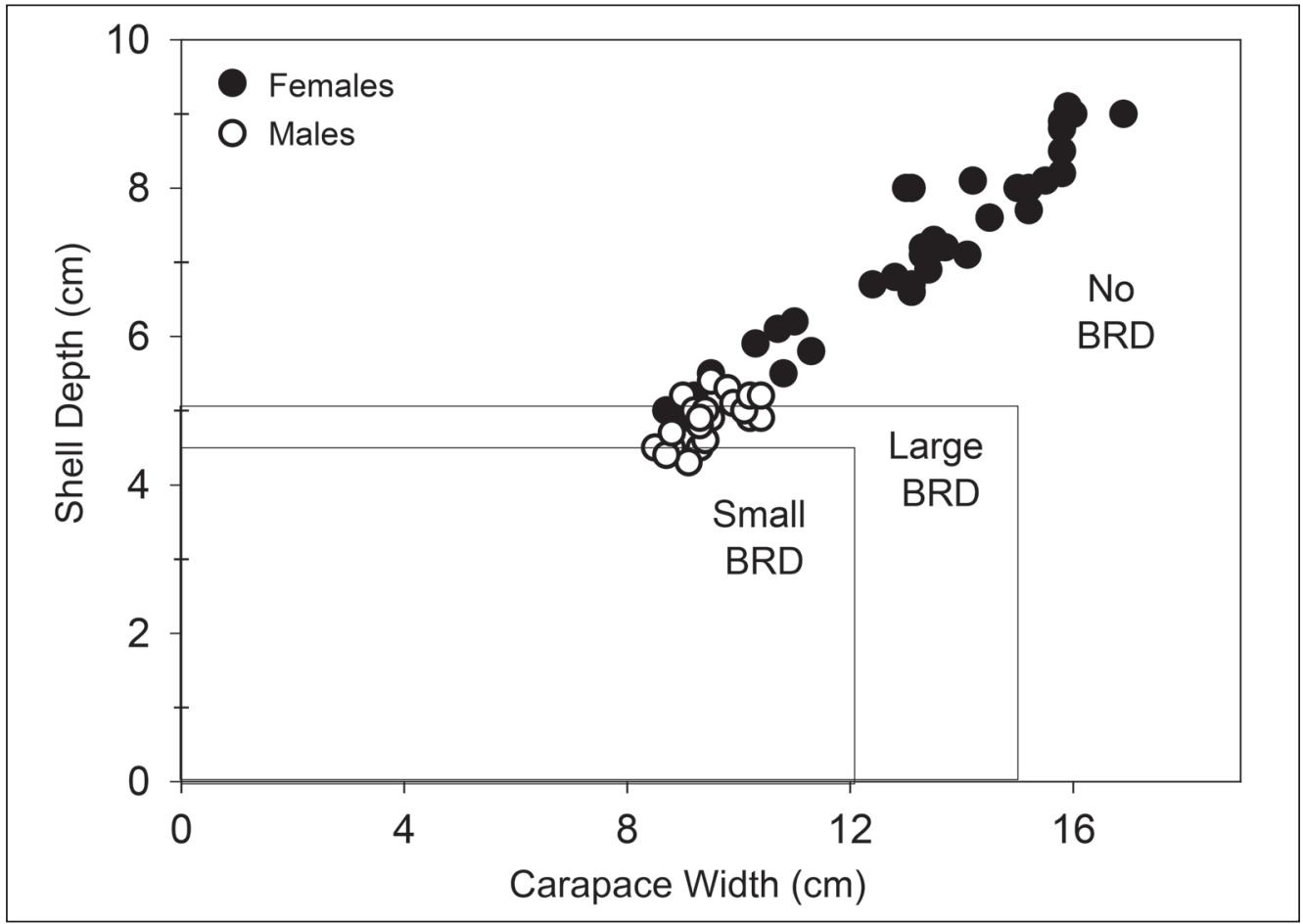

Figure 4. Comparison of captured terrapin dimensions (carapace width and shell depth) with the size of the opening in crab pots created by small BRDs, large BRDs and no BRDs. Terrapins that plot within the dimensions of each BRD are able to enter a crab pot fitted with that BRD, but were not necessarily actually caught in pots fitted with that size BRD (see text). 


\section{Discussion}

By-catch reduction devices on commercial-style crab pots are effective at reducing the capture of terrapins and fish (Table 2). Given the different regulatory strategies regarding BRD implementation by state, our results indicate crabbing success and the risk of by-catch must also vary by state. In MD and DE, recreational crabbing requires the use of small BRDs that appear to be effective in excluding most terrapins and fish. Crab catch in the current study in VA, however, indicated total capture and legal crab size are reduced in pots fitted with small BRDs. Our pots were not baited, so it is possible that baiting could attract more and larger crabs, thereby eliminating any effect of the small BRDs on crab capture. The larger BRDs required by NJ and NY in areas where recreational and commercial crabbing overlap with terrapin habitat also reduced terrapin by-catch significantly but had less of an effect on crab catch and size (Fig. 3), as has been found in prior studies (Hart and Crowder 2011). Both BRD sizes excluded most adult terrapins relative to no BRDs at all.

For unbaited pots without BRDs, we measured an average daily CPUE as high as 0.48 terrapins at one location in Felgates Creek (Fig. 2). This is a very high rate of terrapin by-catch relative to most prior studies (Hart and Crowder 2011, Roosenburg 2004). However, the spatial pattern of crab capture did not match terrapin capture (Fig. 2), suggesting that terrapin and crab distributions and/or activities are independent of each other. Larger and more numerous crabs appear to be concentrated closer to the open water of the York River, and terrapins tend to concentrate in sub-tidal areas adjacent to expansive marshes (Fig. 1). Our work demonstrates that even unbaited pots can trap both crabs and terrapins, sometimes in significant numbers. Morris et al. (2011) found that crab capture tended to be highest in baited pots, whereas terrapin capture was independent of pot baiting. Grosse et al. (2009) reported the drowning of over 90 terrapins in a single untended crab pot. Together, these results demonstrate that untended and unbaited pots can attract, trap, and drown terrapins.

In the absence of BRDs, the estimated loss of $42 \%$ of the terrapin population in Felgates Creek would have occurred in just 24 days of crabbing with 10 pots. Females comprised 33 of the 54 captured terrapins, and although BRDs exclude most adult females, pots without BRDs do not. The potential loss of so many reproductive females from the population would reduce terrapin recruitment dramatically. Because terrapins have limited home ranges (Sheridan et al. 2010), the chronic pressure of crabbing without BRDs has the potential to significantly reduce terrapin population size and alter population demographics (Dorcas et al. 2007).

$\mathrm{BRD}$ regulations in $\mathrm{MD}, \mathrm{DE}, \mathrm{NJ}$, and $\mathrm{NY}$ seek to protect terrapins from drowning in crab pots. To date, however, no studies have been completed that document terrapin population recovery or expansion into areas where BRDs are now being used. Disturbingly, Radzio et al. (2013) estimated less than 35\% compliance with $\mathrm{BRD}$ regulations by recreational crabbers in $\mathrm{MD}$. In the ongoing absence of $\mathrm{BRD}$ regulations in Virginia, $100 \%$ of all recreational crabbing will continue to exert 
negative pressure on terrapin populations. Recreational crab pots are placed nearshore, typically set in the water next to docks of shoreline homeowners who are allowed to fish two pots per person per residence. These pots often are not checked and/or baited daily and thus pose a risk to terrapins because of their nearshore location in terrapin habitat and irregular operation. Lost recreational and commercial pots without BRDs also would pose a risk, as the pots would continue to trap terrapins even without baiting.

The number of docks in tidal waters of Virginia has been estimated at over 20,000 (R.G. Isdell, College of William and Mary, Williamsburg, VA, pers. comm.). If every resident with a dock set and operated just one crab pot, then terrapin mortality bay-wide would likely be very significant, even with a low rate of daily capture. Over a 100-day summer season, for example, with a relatively low average daily CPUE of 0.05 terrapins (Fig. 2), those pots would drown some 100,000 terrapins annually in Chesapeake Bay. From our results, if those same pots were fitted with large BRDs, the recreational crabbers would experience an $18 \%$ reduction in crab catch, but by-catch mortality of terrapins would decrease by $97 \%$.

Although not a direct focus of our study, a substantial amount of commercial crabbing in addition to recreational crabbing is completed in Diamondback Terrapin habitat. Except for NJ and NY, these commercial pots set in tidal creeks are not regulated for BRDs and thus have the potential to impact terrapin populations substantially. Commercial crabbers fish millions of pots daily throughout estuaries of the Atlantic and Gulf Coasts; in some states, many of those pots are placed in shallow tidal creeks. Based on the number and placement of pots in terrapin habitat, the negative effects of commercial crab operations without BRDs could well be just as devastating as recreational crabbing, and in some states may be worse (M.E. Dorcas, Davidson College, Davidson, NC, pers. comm.).

BRD regulations in northeastern states where crabbing and Northern Diamondback Terrapin habitat overlap can be effective in reducing by-catch without affecting crab catch. From the results of the present study in Virginia, the large BRDs $(5 \mathrm{~cm} \times 15.2 \mathrm{~cm})$ reduce terrapin by-catch dramatically without a large reduction in crab catch. Whether targeting recreational crabbers specifically or terrapin habitat more generally, BRD regulations lead to reduced terrapin mortality. Because terrapins also occur in more southern estuaries, coastal states from Virginia to Texas should consider crabbing regulations and the use of BRDs as part of their fisheries management plans.

\section{Acknowledgments}

Terrapin research completed under VA DGIF Permit \#045090 to RMC and College of William and Mary protocol IACUC-2012-04-30-7883-rmcham. A.J. Upperman received funding from the Robert Noyce Teacher Scholarship Program at the College of William of Mary School of Education. Thanks to Captain Crow and the Environmental Division at the Yorktown Naval Weapons Station for access and logistical support. Thanks to C. Sornborger for providing large BRDs. 


\section{Literature Cited}

Bishop, J.M. 1983. Incidental capture of Diamondback Terrapin by crab pots. Estuaries 6:426-430.

Butler, J.A., and G.L. Heinrich. 2007. The effectiveness of bycatch reduction devices on crab pots at reducing capture and mortality of Diamondback Terrapins (Malaclemys terrapin) in Florida. Estuaries and Coasts 30:179-185.

Butler, J.A., G.L. Heinrich, and M.L. Mitchell. 2012. Diet of the Carolina Diamondback Terrapin (Malaclemys terrapin centrata) in Northeastern Florida. Chelonian Conservation and Biology 11:124-128.

Clark, W.S. 1982. Turtles as a food source of nesting Bald Eagles in the Chesapeake Bay region. Journal of Field Ornithology 53:49-51.

Cole, R.V., and T.E. Helser. 2001. Effect of four by-catch reduction devices on Diamondback Terrapin (Malaclemys terrapin) capture and Blue Crab (Callinectes sapidus) harvest in the Delaware estuary. North American Journal of Fisheries Management 21:825-833.

Dorcas, M.E., J.D. Wilson, and J.W. Gibbons. 2007. Crab trapping causes population decline and demographic changes in Diamondback Terrapin over two decades. Biological Conservation 137:334-340.

Gibbons, J.W., J.E. Lovich, A.D. Tucker, N.N. Fitzsimmons, and J.L. Greene. 2001. Demographic and ecological factors affecting conservation and management of Diamondback Terrapins (Malaclemys terrapin) in South Carolina. Chelonian Conservation and Biology 4:66-74.

Grosse, A.M., J.D. van Dijk, K.L. Holcomb, and J. C. Maerz. 2009. Diamondback Terrapin mortality in crab pots in a Georgia tidal marsh. Chelonian Conservation and Biology 8:98-100.

Hart, K.M., and L.B. Crowder. 2011. Mitigating by-catch of Diamondback Terrapins in crab pots. Journal of Wildlife Management 75:264-272.

Heppell, S.S., L.B. Crowder, and T.R. Menzel. 1999. Life-table analysis of long-lived marine species with implications for conservation and management. American Fisheries Society Symposium 23:137-148.

Hoyle, M.E., and J.W. Gibbons. 2000. Use of a marked population of Diamondback Terrapins (Malaclemys terrapin) to determine impacts of recreational crab pots. Chelonian Conservation and Biology 3:735-737.

Mitro, M.G. 2003. Demography and viability analysis of a Diamondback Terrapin population. Canadian Journal of Zoology 81:716-726.

Morris, S.A., S.M. Wilson, E.F. Dever, and R.M. Chambers. 2011. A test of bycatch reduction devices on commercial crab pots in a tidal marsh in Virginia. Estuaries and Coasts 34:386-390.

Radzio, T.A., J.A. Smolinksky, and W.M. Roosenburg. 2013. Low use of required terrapin bycatch reduction devices in a recreational crab pot fishery. Herpetological Conservation and Biology 8:222-227.

Rook, M.A., R.N. Lipcius, B.M. Bronner, and R.M. Chambers. 2010. Bycatch reduction devices conserve Diamondback Terrapins without affecting catch of Blue Crab. Marine Ecology Progress Series 409:171-179.

Roosenburg, W.M. 2004. The impact of crab pot fisheries on terrapin (Malaclemys terrapin) populations: where are we and where do we need to go? Pp. 23-30, In C. Swarth, W.M. Roosenburg and E. Kiviat (Eds.). Conservation and Ecology of Turtles of the MidAtlantic Region: A Symposium. Biblomania, Salt Lake City, UT.

Roosenburg, W.M., and J.P. Green. 2000. Impact of a bycatch reduction device on Diamondback Terrapin and Blue Crab capture in crab pots. Ecological Applications 10:882-889. 
Sheridan, C.M., J.R. Spotila, W.F. Bien, and H.W. Avery. 2010. Sex-biased dispersal and natal philopatry in the Diamondback Terrapin, Malaclemys terrapin. Molecular Ecology 19:5497-5510.

Silliman, B.R., and M.D. Bertness. 2002. A trophic cascade regulates salt marsh primary productivity. Proceedings of the National Academy of Science 99:10,500-10,505.

Tucker, A.D., N.N. Fitzsimmons, and J.W. Gibbons. 1995. Resource partitioning by the estuarine turtle Malaclemys terrapin: Trophic, spatial, and temporal foraging constraints. Herpetologica 51:167-181.

Whitelaw, D.M., and R.N. Zajac. 2002. Assessment of prey availability for Diamondback Terrapins in a Connecticut salt marsh. Northeastern Naturalist 9:407-418.

Wood, R.C. 1997. The impact of commercial crab traps on northern Diamondback Terrapins, Malaclemys terrapin terrapin. Pp. 21-27, In J. Van Abbema (Ed.). Proceedings: Conservation, Restoration, and Management of Tortoises and Turtles-An International Conference. New York Turtle and Tortoise Society, New York, NY. 